\title{
NITROGEN AND POTASSIUM STATUS IN SOIL AS AFFECTED BY FYM RATES, POTASSIUM FERTILIZER LEVELS AND SILICATE BACTERIA \\ Hammad, S. A. ${ }^{1}$; E. M. Selim ${ }^{2}$; M. R. Mohamed ${ }^{3}$ and M. M. EL-Shazly ${ }^{3}$ \\ 1- Soil Dept., Faculty of Agriculture, Mansoura University, Egypt . \\ 2- Soils \& Water Use Dept., National Res Centre (NRC), Doki, Egypt \\ 3- Plant Nutrition Dept., Soil, Water \& Env. Inst., A. R. Centre, Giza.
}

\section{ABSTRACT}

To study the effect of farmyard manure rates $\left(0,10\right.$ and $20 \mathrm{~m}^{3}$ fed $\left.^{-1}\right)$, silicate bacteria (without and with inoculation) and potassium fertilizer levels $(0,50$ and $100 \mathrm{~K}$ $\mathrm{kg} \mathrm{fed}^{-1}$ ) on status of soil-N and K nutrients at different growth stages of potato plants cultivated in alluvial soil, a field experiment was laid out at private farm (Kafr EL-Arab, Talkha, Dakahlia Governorate, Egypt during winter 2005/2006 season. The obtained results could be summarized as follows:

Obtained results show that increasing rates of farmyard manure from 0 up 10 to $20 \mathrm{~m}^{3} \mathrm{fed}^{-1}$, $\mathrm{K}$ fertilizer levels from 0 up 50 to $100 \mathrm{~kg} \mathrm{fed}^{-1}$ and inoculation of silicate bacteria (Bacillus circulans) markedly increased tuber yield (ton fed ${ }^{-1}$ ) of potato plants at 70, 90 and 110 days after planting during (DAP) 2005/2006 season.

Data clear that application of farmyard manure (FYM) had a positive effect on soil-N forms contents i. e. $\mathrm{NO}_{3}^{-}, \mathrm{NH}^{+}{ }_{4}$ and total available $\mathrm{N}$ (TAN) at 70,90 and 110 DAP, respectively.

Also, data reveal that the contents of soil- $\mathrm{NO}_{3}^{-}, \mathrm{NH}^{+}{ }_{4}$ and total available $\mathrm{N}$ (mg $\mathrm{kg} \mathrm{soil}^{-1}$ ) slightly affected due to inoculation of silicate bacteria as compared to the control, respectively. Moreover, application of $\mathrm{K}$ fertilizer had a slight effect on contents of soil- $\mathrm{NO}_{3}{ }_{3}$ and total available $\mathrm{N}\left(\mathrm{mg} \mathrm{kg} \mathrm{soil}^{-1}\right)$. Meanwhile, there is a descent trend on soil- $\mathrm{NH}^{+}{ }_{4}$ content due to increasing levels of potassium fertilizer at 70, 90 and 110 DAP during 2005/2006 season.

Statistical analysis reveal that, the addition of farmyard manure 0 up 10 to 20 $\mathrm{m}^{3} \mathrm{fed}^{-1}$, silicate bacteria (Bacillus circulans) and $\mathrm{K}$-fertilizer from 0 up to 50 and $100 \mathrm{~K}$ $\mathrm{kg} \mathrm{fed}^{-1}$ caused vigorously enhancing in available soil-K content (mg kg soil ${ }^{-1}$ ) at different growth stages of potato crop at 70, 90 and 110 DAP.

Multiple linear regression from the following equation revealed that $\mathrm{N}$-forms and available soil- $\mathrm{K}$ had a pronounced effect on predicting the tuber yield (ton fed ${ }^{-1}$ ) of potato plants $\left(r^{2}=88.5 \%\right)$.

The expected equation to predict the tuber yield was:-

Tuber yield $\left(\right.$ ton fed $\left.{ }^{-1}\right)=3.73+0.131$ soil- $\mathrm{NO}^{-}{ }_{3}-0.165$ soil- $\mathrm{NH}^{+}{ }_{4}+0.284$ soil-TAN +0.641 available soil-K.

Keywords:FYM, Silicate bacteria, K fertilizer, Soil-N forms, Available soil-K

\section{INTRODUCTION}

Potato (Solanum tuberosum L.) has a very exhausting effects on soil fertility. Its growth is responsible for a liberal dressing of readily available nutrients. Supplying the necessary nutrients in the correct proportion may be produced high yield and satisfactory tubers.

Organic farming covers agriculture systems that implement the environmentally, socially and economically sound production of food. These 
systems take local soil fertility as the basis of there production capacity and by respecting the inherent nature of plants, animals manures, legumes, green manure and off-farm organic wastes (Abou-Hussien, 2002a). Also, biofertilizers are products containing living cells of different micro-organism types, which have the ability to convert nutritionally important elements from unavailable to available form through biological processes (Vessey, 2003).

In most long term experiments, combination mineral fertilizer and farmyard manure has generally given the best crop yields and soil quality many parts of the world (Bogdevitch et al., 2002); Wahdan, 2004; Wang et al., 2004).

El-Fayoumy and Hammad (2001) found that availability of soil-N and $\mathrm{K}$ was increased by $17.49,75.51$ and $13.57 \%$ respectively as affected by FYM application up to $20 \mathrm{~m}^{3} / \mathrm{fed}$. Moreover, Li-YuYing (2002) and Kovaevic et al., (2005) demonstrated that the application of $100 \mathrm{~kg} \mathrm{~K}$ 决a for soil with very low status (less than $5 \mathrm{mg} \mathrm{K} \mathrm{K}_{2} \mathrm{O} / 100 \mathrm{~g}$ in $0-30 \mathrm{~cm}$ soil depth).

A great deal of researches was conducted on the role of microorganisms in mobilizing potassium, silicon and aluminum represented by a group of bacteria given the name "silicate bacteria". These studies led to a preparation of a Biofertilizers called "silico-bacterin" which proved to be capable of decomposing aluminosilicate minerals and enduring potassium to available form for the growing plants. In addition, several investigators reported that the efficiency of organic manures in the presence of biofertilizers were highest in availability of soil- $\mathrm{N}$ and $\mathrm{K}$ (Ashour et al., 2004; Abdel-Hady et al., 2005 and Sheng, Mao, et al., 2006).

Therefore, this investigation aims to study and discuss the status of $\mathrm{N}$ and $\mathrm{K}$ in the studied soil as affected by farmyard manures, silicate bacteria and potassium fertilizer levels at different growth stages of potato plants during the winter of 2005/2006 season.

\section{MATERIALS AND METHODS}

To study the effect of farmyard manure rates, silicate bacteria and potassium fertilizer levels on status of soil- $\mathrm{N}$ and $\mathrm{K}$ nutrients at different growth stages of potato plants cultivated in alluvial soil. A field experiment was laid out at private farm (Kafer EL-Arab, Talkha, Dakahlia Governorate, Egypt during winter 2005/2006 season. The studied soil is considered a clay loam in texture. Some physical and chemical properties of the studied soil presented in Table 1.

Table 1: Some physical and chemical properties of the studied soil.

\begin{tabular}{|c|c|c|c|c|}
\hline \multicolumn{2}{|l|}{ Property } & Value & Property & Value \\
\hline Sand & \multirow{3}{*}{$\%$} & 18.58 & $\mathrm{ECe}$ (soil paste extract) dSm ${ }^{-1}$ & 2.93 \\
\hline Silt & & 38.02 & pH (1:2.5 soil: water suspension) & 7.4 \\
\hline Clay & & 43.40 & \multicolumn{2}{|c|}{ Available nutrients (mg kg soil- ${ }^{-1}$ ) } \\
\hline \multicolumn{3}{|c|}{ Textural grade: Clay loam } & $\mathrm{NO}_{3}^{-}$ & 62.97 \\
\hline \multirow{2}{*}{ Organic Matter } & \multirow{2}{*}{$\%$} & \multirow{2}{*}{1.89} & $\mathrm{NH}_{4}^{+}$ & 13.05 \\
\hline & & & Total avail. $\mathbf{N}$ & 76.02 \\
\hline & & & $\mathbf{P}$ & 17.5 \\
\hline & & & $\mathbf{K}$ & 380 \\
\hline
\end{tabular}


Farmyard manure applied at three rates 0,10 and $20 \mathrm{~m}^{3} \mathrm{fed}^{-1}$ and were incorporated, then soil was irrigated and left for 15 days before sowing. Some chemical properties of the investigated organic manure illustrated in Table 2.

Table2:Some chemical properties of the investigated organic manure

\begin{tabular}{|c|c|c|c|c|c|c|c|c|c|}
\hline \multirow[t]{2}{*}{ Source } & \multicolumn{3}{|c|}{$\begin{array}{c}\text { Available } \\
\text { Nutrients (\%) }\end{array}$} & \multirow{2}{*}{$\begin{array}{l}\text { Wight of } \\
\mathrm{m}^{3}(\mathrm{~kg})\end{array}$} & \multirow{2}{*}{$\begin{array}{l}\text { Moist. } \\
\%\end{array}$} & \multirow{2}{*}{$\begin{array}{c}\text { O. C } \\
\%\end{array}$} & \multirow{2}{*}{$\underset{\%}{\text { O. M }}$} & \multirow{2}{*}{$\begin{array}{c}\mathrm{C} / \mathrm{N} \\
\text { ratio }\end{array}$} & \multirow{2}{*}{\begin{tabular}{|c|}
$\mathrm{pH}$ \\
(1:2.5 water \\
suspension)
\end{tabular}} \\
\hline & $\mathbf{N}$ & $\mathbf{P}$ & $\mathrm{K}$ & & & & & & \\
\hline FYM & 1.2 & 0.29 & 2.0 & 535 & 23.5 & 42.0 & 14.0 & $21: 1$ & 8.6 \\
\hline
\end{tabular}

Efficient inoculants of the biofertilizer silicates decomposing (Bacillus circulans) were obtained from Integrated Control Res. Dept., Plant Pathology Res. Inst., Agric. Res. Center, Giza. The prepared biofertlizer was added to feldspar at rate of $50 \mathrm{ml} / \mathrm{kg}$ of each other to the soil immediately before the first irrigation.

Potassium sulphate $(41.5 \% \mathrm{~K})$ levels were divided into two equal doses and applied with the $2^{\text {nd }}$ and the $3^{\text {rd }}$ additions of $\mathrm{N}$. All agricultural practices of planting were done as recommended by Ministry of Agriculture. Potato pieces were cultivated on October $16^{\text {th }} 2005$ and tubers were harvested at 70,90 and 110 DAP of potato plants to record the tuber yield (ton fed $^{-1}$ ).

The experimental design was split plot design where, main plots were assigned to the three farmyard manure rates $\left(0,10\right.$ and $\left.20 \mathrm{~m}^{3} \mathrm{fed}^{-1}\right)$, while the silicate bacteria as a source for silicate decomposing bacteria were (without and with inoculation) done in sub plots, and the three levels of potassium $\left(0,50\right.$ and $\left.100 \mathrm{~K} \mathrm{~kg} \mathrm{fed}^{-1}\right)$ were assigned in the sub-sub plots. Hence, the total number of present trial was 3 levels $(F Y M) \times 2$ rates (Bio) $\times 3$ levels $(K)=18$ treatments. The plot area was $17.5 \mathrm{~m}^{2}$ (1/240 feddan) which contained 5 ridges, each $5 \mathrm{~m}$ long and $0.7 \mathrm{~m}$ width and each treatment was replicated 3 times to give a total number of 54 experimental units.

Random soil samples were collected from $(0-30 \mathrm{~cm})$ soil depth at aforementioned days after planting (70,90 and $110 \mathrm{DAP})$ of potato plant to determine soil- $\mathrm{N}$ forms (i. e. $\mathrm{NO}_{3}^{-}, \mathrm{NH}^{+} 4$ and available $\mathrm{N}(\mathrm{mg} \mathrm{kg}$ soil-1) and available soil-K (mg kg soil $\left.{ }^{-1}\right)$ as mentioned by (Hesse, 1971). All data were statistically analyzed according to the technique of analysis of variance (ANOVA) and the least significant differences between the treatment means were compared as published by Gomez and Gomez (1984). Finally, the obtained data of the tuber yield $(\mathrm{Y})$ and $\mathrm{N}$ forms and available $\mathrm{K}$ contents in soil were subjected to simple correlation and regression. Also, the results of aforementioned characters were subjected to multiple linear regression and path coefficient analysis. Partial coefficient of determination $\left(\mathrm{r}^{2}\right)$ was estimated for each component to evaluate the relative contribution and to construct the prediction model of the tuber yield $(\mathrm{Y})$ according to the following formula:-

$Y=a+b_{1} x_{1}+b_{2} x_{2}+b_{3} x_{3}+b_{4} x_{4} \ldots$ (Snedecor and Cochran, 1982). 
Hammad, S. A. et al.

\section{RESULTS AND DISCUSSION}

\section{Tuber yield:-}

\subsection{Effect of farmyard manure rates:-}

Concerning the effect of FYM rates on tuber yield, Fig 1 reveals that, tuber yield (ton fed ${ }^{-1}$ ) was markedly increased at 70, 90 and 110 DAP, respectively. The highest mean values of tuber yield were $(3.42,4.54$ and 18.88 ton fed ${ }^{-1}$ ) obtained from the treatment of FYM $20 \mathrm{~m}^{3} \mathrm{fed}^{-1}$ at 70,90 and 110 DAP, respectively. Meanwhile, the lowest mean values of previous attribute were $\left(1.52,3.09\right.$ and 14.33 ton $\mathrm{fed}^{-1}$ ) obtained from the untreated plants at the same days after planting during 2005/2006 season. The increase \% for the two treatments over control after 110 DAP amounted to about 21.2 and $31.8 \%$, respectively. Generally, the beneficial effects of organic manure on vegetative growth might be related to that the application of organic materials improved the physical conditions of the soil, provided energy for microorganisms activity, increased nutrient supply and improved the efficiency of macro elements as well as its ability to meet some micro nutrient requirements (Tisdale et al., 1985).

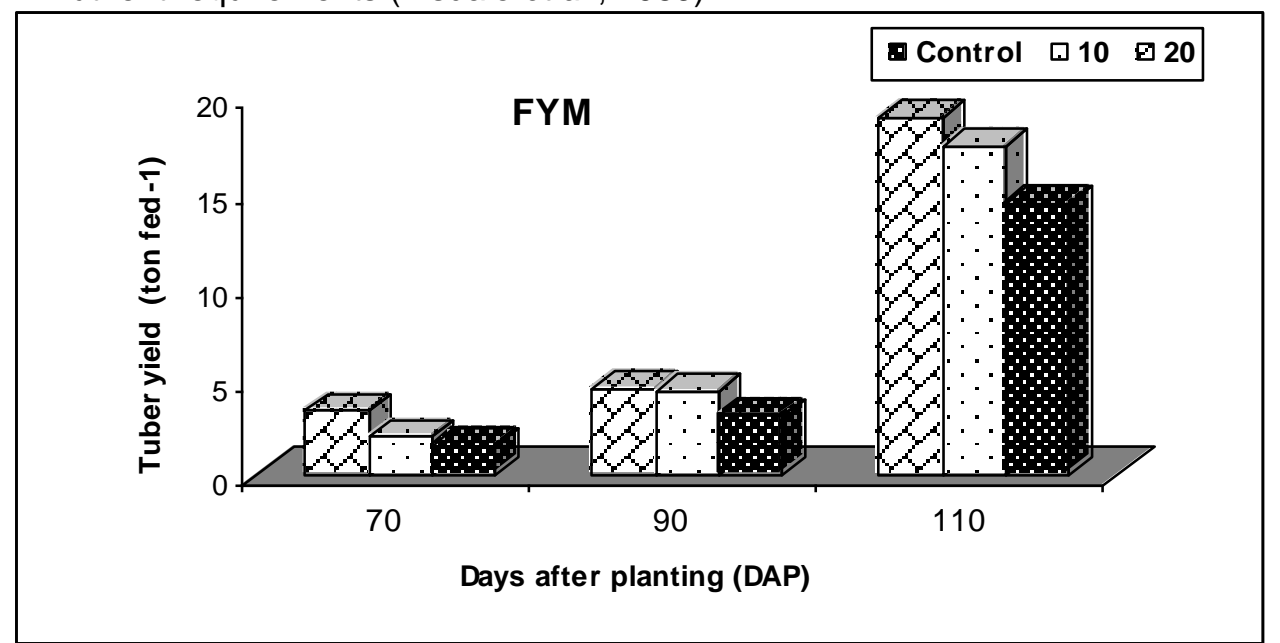

Fig 1: Tuber yield (ton fed ${ }^{-1}$ ) as affected by farmyard manure rates, silicate bacteria and $\mathrm{K}$ fertilizer treatments.

\subsection{Effect of silicate bacteria:-}

Except for tuber yield at 90 ADP, silicate bacteria (Bacillus circulans) gave a positive effect on tuber yield as compared with the control at 70 and 110 DAP, respectively (Fig 2). Also, Fig 2 reveals that, the maximum mean values of tuber yield were $\left(2.52,4.18\right.$ and 17.61 ton $\left.^{-1} \mathrm{fed}^{-1}\right)$ obtained from plants treated with silicate bacteria, respectively. Meanwhile, the minimum mean values of this attribute were $(2.12,3.87$ and 16.11) obtained from the check treatment at the same previous days after planting, respectively. These results are confirmed with those of El-Banna et al., (2001) and Ramadan, (2007) on potato plants. 


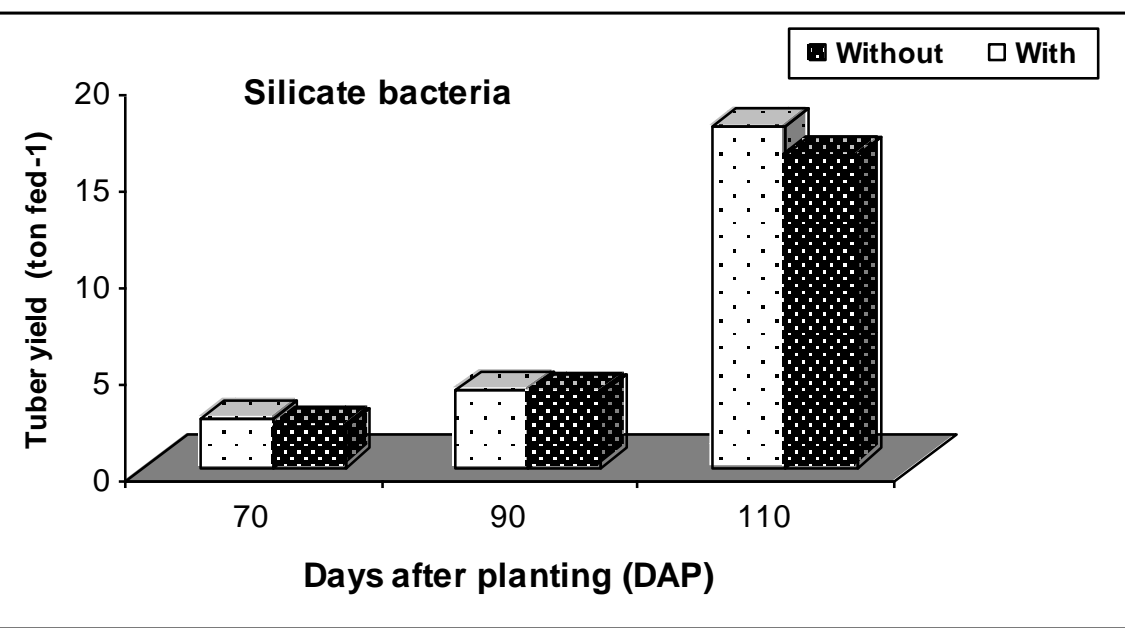

Fig 2:Tuber yield (ton fed $^{-1}$ ) as affected by silicate bacteria treatments.

\subsection{Effect of $K$ fertilizer levels:-}

The additional levels of $\mathrm{K}$ fertilizer increased tuber yield of potato plants at 70, 90 and 110 DAP during the growth season. The maximum mean values of tuber yield were $\left(2.52,6.50\right.$ and 17.60 ton $^{f^{-1}} \mathrm{~d}^{-1}$ ) obtained from the addition of $100 \mathrm{~K} \mathrm{~kg} \mathrm{fed}^{-1}$ at 70,90 and $110 \mathrm{DAP}$, respectively. Meanwhile, the minimum mean values of the fresh tuber yield were $(2.20,4.00$ and 14.20 ton $\left.\mathrm{fed}^{-1}\right)$ produced from the control at the different growth stages, respectively. Potassium plays vital role in physiological processes inside the plant, enzyme activities, water absorption, transpiration and increasing the outward translocation of photosynthesis from the above ground parts to the subterranean storage root organs (roots). These results are agreeable with those obtained by Arisha and Bardisi (1999); Abdel-Kader (2002) and Selim (2003).

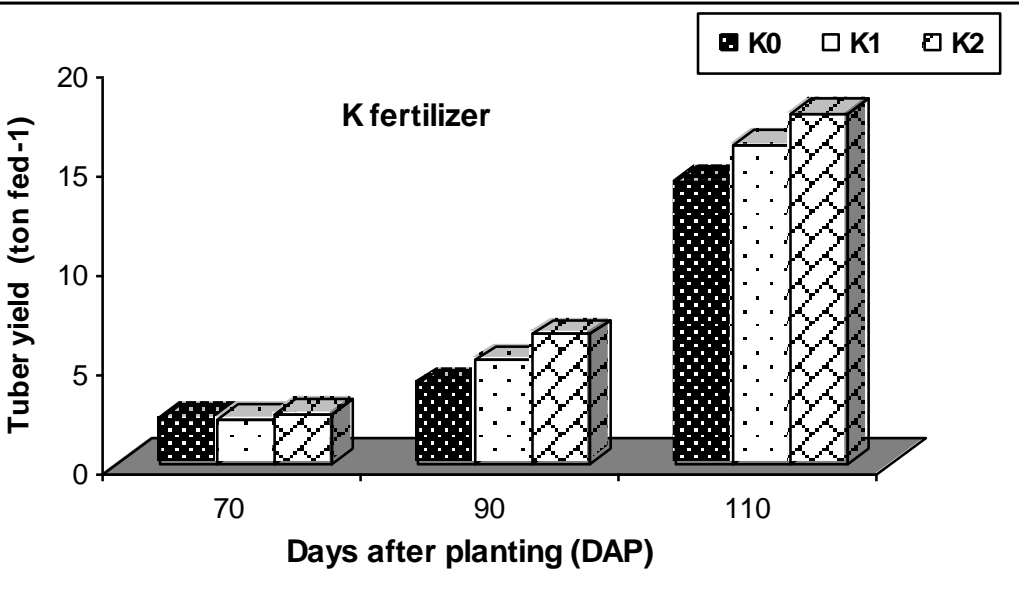

Fig 3: Tuber yield (ton fed $^{-1}$ ) as affected by as affected by $\mathrm{K}$ fertilizer levels. 


\section{Nitrogen forms in soil (mg kg soil $\left.{ }^{-1}\right)$ :-}

\subsection{Effect of farmyard manure rates :-}

As shown in Table1, data clear that application of FYM had a positive effect on soil- $\mathrm{N}$ forms contents i. e. $\mathrm{NO}_{3}{ }_{3} \mathrm{NH}^{+} 4$ and total available $\mathrm{N}$ at 70,90 and 110 DAP respectively, during 2005/2006 season. The highest mean averages of soil-NO-${ }_{3}$ content were $\left(72.48,68.83\right.$ and $\left.74.29 \mathrm{mg} \mathrm{kg} \mathrm{soil}^{-1}\right)$ occurred with added rate $20 \mathrm{~m}^{3} \mathrm{fed}^{-1}$ of FYM at 70,90 and 110 DAP, respectively. Meanwhile, the lowest mean averages of this soil- $\mathrm{N}$ form were (64.07, 64.51 and $64.47 \mathrm{mg} \mathrm{kg} \mathrm{soil}^{-1}$ ) obtained from the control at the same growth stages, respectively. The increase \% of soil-NO-3 contents for the two treatments after harvest over the control amounted to about 6.53 and $15.23 \%$, respectively.

Table3: Means of soil-N forms (mg kg soil-1) as affected by farmyard manure rates, silicate bacteria and $K$ fertilizer treatments at days after planting.

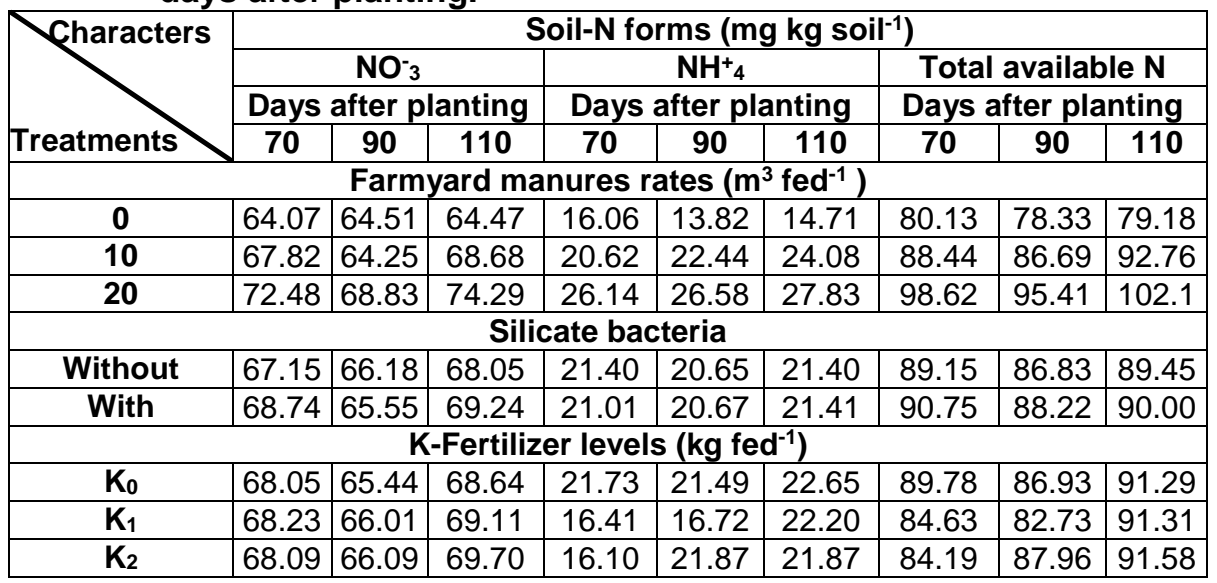

With respect to soil- $\mathrm{NH}^{+}{ }_{4}$ content ( $\mathrm{mg} \mathrm{kg} \mathrm{soil}^{-1}$ ), the highest averages of this form were $\left(26.14,26.58\right.$ and $\left.27.83 \mathrm{mg} \mathrm{kg} \mathrm{soil}^{-1}\right)$ produced from $20 \mathrm{~m}^{3}$ fed 1 of FYM. Whereas, the lowest averages were $(16.06,13.82$ and $14.71 \mathrm{mg} \mathrm{kg}$ soil- $^{-1}$ ) produced from the control at 70, 90 and $110 \mathrm{DAP}$, respectively. The increase $\%$ of soil- $\mathrm{NH}^{+} 4$ contents for these treatments over the control reached to about 63.70 and $89.19 \%$ at 110 days after planting, respectively.

The same Table clearly appears that the received plots $20 \mathrm{~m}^{3} \mathrm{fed}^{-1}$ contained the highest averages of this form of soil- $\mathrm{N}$ as compared to the untreated plots at 70, 90 and $110 \mathrm{DAP}$, respectively. The increase $\%$ of total available soil- $\mathrm{N}$ (mg kg soil-1) for these treatments over control reached to about 17.15 and $28.97 \%$ after 110 DAP, respectively. In this respect, Hammad (1996) concluded that the addition of organic fertilizers to the soil can improve its physical and biological properties, which are reflected generally, on soil fertility status and thus the dynamic changes of $\left(\mathrm{NH}^{+}{ }_{4}+\mathrm{NO}\right.$ 3) $-\mathrm{N}$ in the upper $20 \mathrm{~cm}$ of soil could be influenced, to a great extent, by organic fertilization during all growth periods. But, Sheng Mao et al., (2006) 
reported that the application of farmyard manure along with the mineral fertilizers markedly reduced residual $\mathrm{NO}_{3}-\mathrm{N}$ accumulation in the examined soil profiles.

\subsection{Effect of silicate bacteria:-}

Table 3 shows that mean values of soil- $\mathrm{NO}_{3}^{-}, \mathrm{NH}^{+} 4$ and total available $\mathrm{N}$ (mg kg soil-1) slightly and negligible affected due to inoculation of silicate bacteria as compared to the control at 70,90 and 110 DAP, respectively during 2005/2006 season.

\subsection{Effect of $K$ fertilizer levels :-}

From results presented in Table 3 , it could be concluded that application of potassium fertilizer had a marked effect on soil-NO ${ }_{3} 3$ contents (mg kg soil-1) at 70, 90 and 110 DAP during 2005/2006 season. Meanwhile, there is a descent trend with increasing levels of potassium fertilizer from 0 up 50 to $100 \mathrm{~K} \mathrm{~kg} \mathrm{fed}^{-1}$ on soil- $\mathrm{NH}^{+}{ }_{4}$ and total available $\mathrm{N}\left(\mathrm{NO}_{3}{ }_{3}+\mathrm{NH}^{+}{ }_{4}\right)$ contents at the same periods, respectively. The fertilized plots with $100 \mathrm{~K} \mathrm{~kg}$ fed $^{-1}$ caused the highest mean of soil- $\mathrm{NO}^{-} 3$ content $\left(69.70 \mathrm{mg} \mathrm{kg} \mathrm{soil}^{-1}\right)$ at 110 DAP. But, the lowest value of this form was $\left(65.44 \mathrm{mg} \mathrm{kg} \mathrm{soil}^{-1}\right)$ in the untreated plots at 90 DAP.

The highest value of soil- $\mathrm{NH}^{+} 4$ content $\left(22.65 \mathrm{mg} \mathrm{kg} \mathrm{soil}{ }^{-1}\right)$ was obtained from the untreated soil $\left(\mathrm{K}_{0}\right)$ at 110 days after planting, and, the lowest value of this form was $\left(16.10 \mathrm{mg} \mathrm{kg} \mathrm{soil}^{-1}\right)$ occurred with the same level at 70 DAP. In addition, the application of potassium fertilizer had a negligible effect on total available soil- $\mathrm{N}\left(\mathrm{mg} \mathrm{kg} \mathrm{soil}^{-1}\right)$ at 70,90 and 110 DAP.

\section{Available soil-K contents (mg kg soil ${ }^{-1}$ )}

\subsection{Effect of farmyard manure rates:-}

The application of FYM, silicate bacteria and $\mathrm{K}$ fertilizer markedly affected the contents of this soil- $\mathrm{K}$ ( $\mathrm{mg} \mathrm{kg} \mathrm{soil}^{-1}$ ) as compared to the control at 70, 90 and 110 DAP (Fig 4).

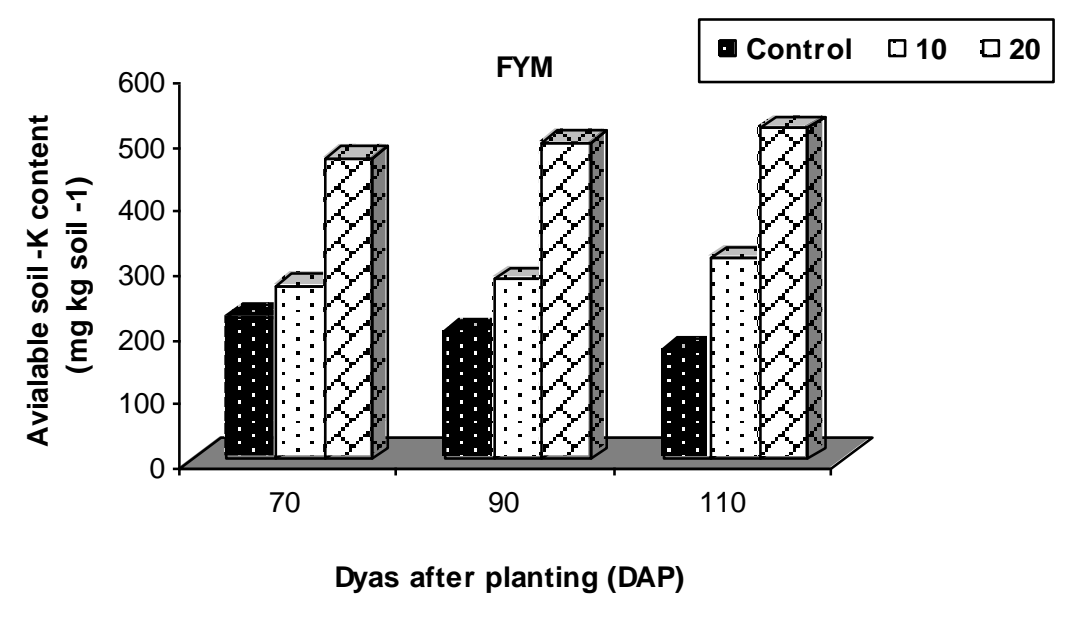

Fig 4: Available soil-K contents (mg kg soil- ${ }^{-1}$ ) as affected by farmyard manure rates $\left(\mathrm{m}^{3} \mathrm{fed}^{-1}\right)$. 
Hammad, S. A. et al.

The farmyard manure addition caused vigorously enhancing in content of available soil- $\mathrm{K}\left(\mathrm{mg} \mathrm{kg} \mathrm{soil}^{-1}\right)$ at different growth stages of potato crop. The highest mean averages of available soil-K content were (468, 491 and 514.8 $\mathrm{mg} \mathrm{kg} \mathrm{soil-1)}$ obtained from the level of $20 \mathrm{~m}^{3} \mathrm{fed}^{-1}$ at 70, 90and 110 DAP, respectively. While the lowest mean averages were (222.3, 195.0 and 167.6 mg kg soil-1) occurred with the control treatment. The percentage increases of soil-K were ( 86.16 and $207.15 \%$ ) occurred with 10 and $20 \mathrm{~m}^{3} \mathrm{fed}^{-1}$ over the control at $110 \mathrm{DAP}$, respectively. It may be attributed to the mineralization of organic minerals and slow release of minerals in an available form from organic manure; these results are in agreement with those of Ashour et al., (2004); Abdel-Hady et al., (2005) and El-Mancy, and Selim (2007).

\subsection{Effect of silicate bacteria:-}

The inoculated plots that with silicate bacteria (Bacillus circulans) contained available soil- $\mathrm{K}$ ( $365.3,371.8$ and $380.9 \mathrm{mg} \mathrm{kg} \mathrm{soil}^{-1}$ ) more than untreated plots at 70,90 and 110 DAP, respectively during 2006/2005 season (Fig 5).

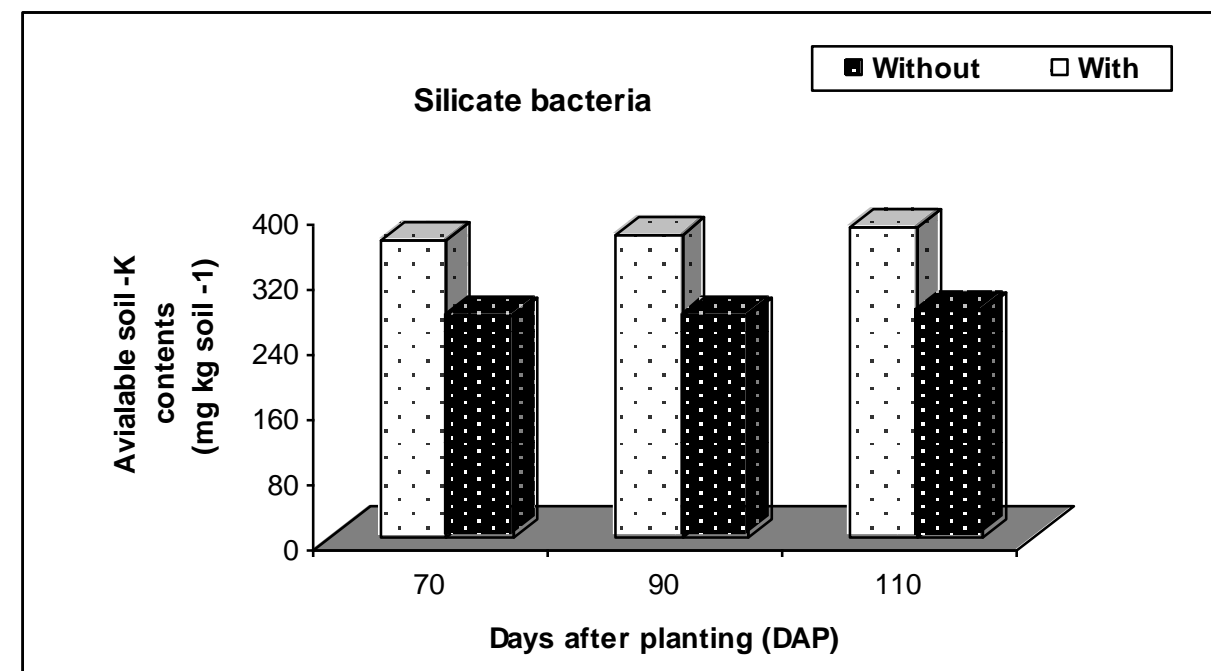

Fig 5: Available soil-K contents (mg kg soil-1) as affected by silicate bacteria.

\subsection{Effect of $K$ fertilizer levels:-}

The available soil- $K$ content ( $\mathrm{mg} \mathrm{kg} \mathrm{soil}^{-1}$ ) approximately increased with the additional levels of K-fertilizer from 0 up to 50 and $100 \mathrm{~K} \mathrm{~kg} \mathrm{fed}^{-1}$ at 70,90 and 110 DAP. The highest means of available soil-K content were $(659,663$ and $666 \mathrm{mg} \mathrm{kg} \mathrm{soil}^{-1}$ ) with $100 \mathrm{~kg} \mathrm{fed}^{-1}$ of $\mathrm{K}$ fertilizer. But, the lowest mean values of this form were $\left(235,218\right.$ and $\left.200 \mathrm{mg} \mathrm{kg} \mathrm{soil}^{-1}\right)$ in the control at 70 , 90 and 110 DAP, respectively (Fig 6). So, Li-YuYing (2002) reported that available $\mathrm{K}$ content in soil decreased significantly each year. In the contrast, without applying potash fertilizer, the content of slow-releasing $\mathrm{K}$ in soil decreased quickly, while in potash-treated plots it decreased slightly. 


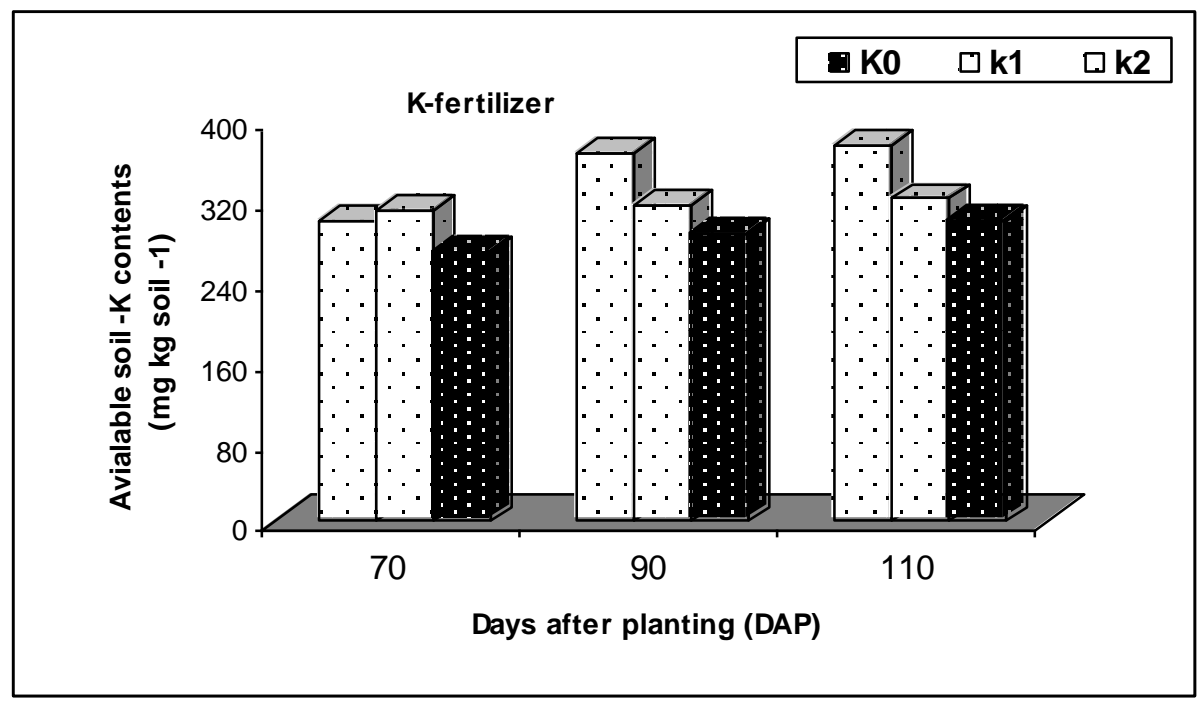

Fig 6: Available soil-K contents ( $\mathrm{mg} \mathrm{kg} \mathrm{soil}^{-1}$ ) as affected by $\mathrm{K}$ fertilizer levels.

The statistical analysis reveal that tuber yield (ton $\mathrm{fed}^{-1}$ ) of potato plants was a highly significant correlated among all soil- $\mathrm{N}$ forms and available soil- $\mathrm{K}$ ( $\left.\mathrm{mg} \mathrm{kg} \mathrm{soil}{ }^{-1}\right)$. The simple correlation coefficient values between tuber yield and these characters were; $0.91^{* *}, 0.91^{*}, 0.93^{*}$ and $0.86^{*}$, respectively. Meanwhile, Multiple linear regression from the following equation revealed that $\mathrm{N}$-forms and available soil- $\mathrm{K}$ had a pronounced effect on predicting the tuber yield (ton fed $\left.{ }^{-1}\right)$ of potato plants $\left(r^{2}=88.5 \%\right.$ and the adj. $.^{2}=83.7 \%$ ).

The expected equation to predict the tuber yield was:-

Tuber yield $\left(\right.$ ton fed $\left.{ }^{-1}\right)=3.73+0.131$ soil- $^{-N^{-}}{ }_{3}-0.165$ soil- $\mathrm{NH}^{+}{ }_{4}+0.284$ soil-TAN + 0.641 available soil-K.

As shown in above formula, tuber yield (ton fed ${ }^{-1}$ ) was positively increased due to soil- $\mathrm{NO}_{-3}^{-}$content $\left(\mathrm{mg} \mathrm{kg} \mathrm{soil}^{-1}\right)$ and total available nitrogen (TAN) $\left(\mathrm{NH}^{+}{ }_{4}+\mathrm{NO}_{3}^{-}\right)$. This result may be attributed to that organic matter had a significant effect on $\mathrm{NH}^{+}{ }_{4}$ and its decomposition of manure and release $\mathrm{N}$ forms especially $\mathrm{NH}^{+}{ }_{4}$ content.

As illustrated in Fig 7, simple regression equation for predicting the

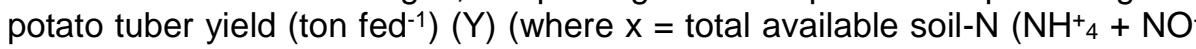
3) was computed from the quadratic equation as follow:

$$
Y=-55.3176+1.40632 X-6.67 E-03 X^{\star \star 2}\left(r^{2}=90.1 \%\right) \text {. }
$$




\section{Regression Plot}

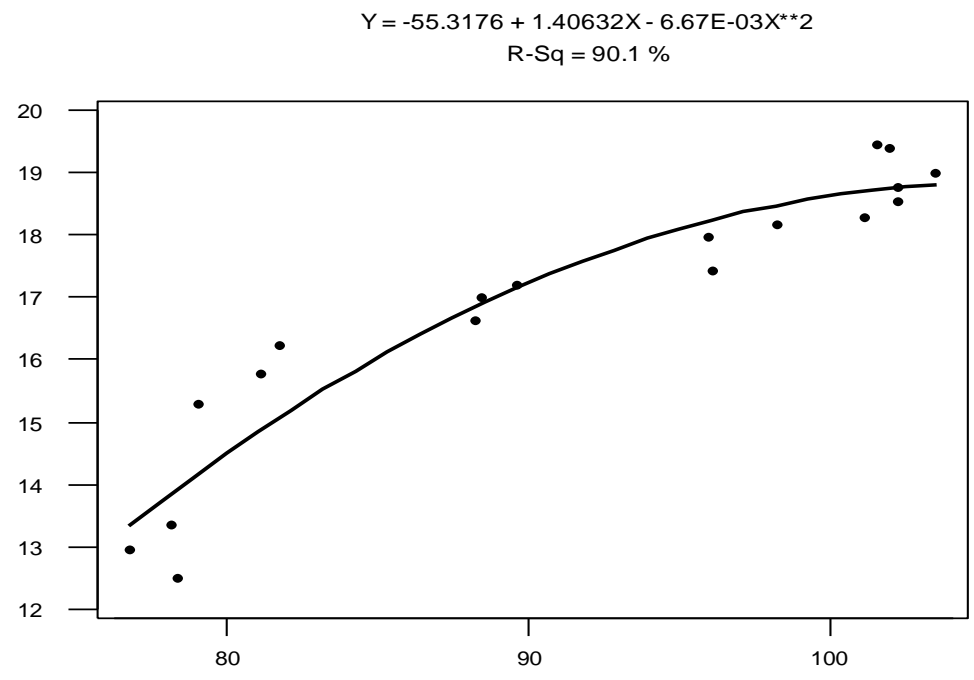

Total avialable $\mathrm{N}$ in soil ( $\mathrm{mg} \mathrm{kg}$ soil-1)

Fig 7: Simple regression coefficient between potato tuber yield and TAN $\left(\mathrm{NH}_{4}^{+}+\mathrm{NO}_{3}^{-}\right)$as affected by the studied treatments.

\section{Conclusion}

It could be concluded that $\mathrm{N}$-forms and available $\mathrm{K}$ in soil had a pronounced effect $\left(\mathrm{r}^{2}=88.5 \%\right)$ on predicting the tuber yield (ton fed $\left.{ }^{-1}\right)$ of potato plants by application $20 \mathrm{~m}^{3} \mathrm{fed}^{-1}$ of farmyard manure $+100 \mathrm{~K} \mathrm{~kg} \mathrm{fed}^{-1}$ in presence of silicate bacteria (Bacillus circulans) at different growth stages.

\section{REFERENCES}

Abdel-Hady, B. A. Camilia Y. El-Dewiny and M. R. Abdel-Mooez (2005). Effect of inorganic fertilizer and organic residues on growth and NPK content by rocket plants. Egypt, J. Appl. Sci., 20(6A):347-357.

Abdel-Kader, A. E. (2002). Effect of some organic and mineral fertilizers on some potato cultivars (solanum tuberosum I.). M. Sc. Thesis. Fac. Agric., Mansoura Univ., Egypt.

Abou- Hussein, S. D.; I. El-Oksh; T. El-Shorbagy and A.M. Gomaa (2002a). Effect of cattle manure, biofertilizers and reducing mineral fertilizer on nutrient content and yield of potato plant. Egypt. J. Appl. Sci., 29 (1): $99-115$.

Arisha, H. M. and A. Bardisi. (1999). Effect of mineral and organic fertilizers on growth, yield and tuber quality of potato under sandy soil conditions. Zagazig J. Agric. Res., 26(2): 391-409.

Ashour, I. A.; M. Ali and F. A. Hashem (2004). Efficiency of using amendments and biofertilizers fopr controlling salinity and alakalinity of soil. Egypt, J. Appl. Sci., 19(7b):772-783. 
Bogdevitch,-I-M; S. V. Tarasyuk, V. A. Dovnar (2002). Influence of manure and mineral fertilizers on the yield of agricultural crops of the link crop rotation. Pochvovedenie-i-Agrokhimiya. 2002; 32: 60-68, 307, 321.

EL-Banna, E. N.; Awad, E. N.; Ramadan, H. M. and Mohamed, M. R. (2001). Effect of bio-organic fertilization in different seasons on growth, yield and tubers quality of potato (Selenium Tuberosum) J. Agric. Sci. Mansoura Univ., 26 (3): 1873-1882.

El-Fayoumy, M. E. and K. M. Hammad (2001). Calcareous soil and sesam productivity improvement in relation to organic fertization and frequency of irrigation. J. Agric. Sci. Mans. Univ., 26 (3): 1811-1832. : 250-255. Choudhury, M.R.; N.C.

El-Mancy, M. H. A. and E. M. Selim (2007). Productivity of tomato plants treated with some biological, organic and inorganic fertilizers. Egypt, J. Appl. Sci., (In Press).

Gomez, K. A. and A. A. Gomez (1984). "Statistical Procedures for Agricultural Research". $2^{\text {nd }}$ Ed. John Wiely and Sons, pp. 680.

Hammad, S. A. (1996). Statues and behavior of nitrogen in soils under different conditions. A review. J. Agric. Sci. Mansoura Univ., 21 (4):1559-1587.

Hesse, P. R. (1971). "A Text Book of Soil Chemical Analysis". John Murry (publishers) Ltd, 50 Albermarle Street, London.

Kovaevic,V; D. Petosic, M. Josipovic (2005). Potassium availability in hydromorphic soils of Eastern Croatia. Faculty of Agriculture, University J. J. Strossmayer in Osijek, Trg Sv. Trojstva 3, HR- 31000 .sijek,Croatia.Cereal-Research-Communications.2005; 33 (1): 247250.

Li-YuYing (2002). Influence of successive application of potash fertilizer on dynamic change of potassium in black soil. Institute of Soil and Fertilizer, Heilongjiang Academy of Agricultural Sciences, Harbin 150086, Heilongjiang, China. Soils-and-Fertilizers-Beijing. 2002; (3): 20.

Ramdan, E. A. (2007). Effect of bio- and minéral fertilezers on growth, yield and quality of potato plants. Ph. D. Thesis, facet. ofAgric. Mansoura Univ.(2007).

Selim, E. M. (2003). Fertigation of drip irrigated potatoes. Ph. D. Thesis. Fac. Agric., Mansoura Univ., Egypt.

Sheng Mao, Y.; L. Feng Min; G. Tian-Wen; W. Jian Guo; S. Bing Ling and J. Shao Ling (2006): Effect of long term fertilization on soil productivity and nitrate accumulation in Gansu Oasis. Agricultural Science in China. 5(1): 57-67.

Snedecor, G. W. and Cochran, W. G. (1982). "Statistical methods". $7^{\text {th }}$ Ed. Second printing. The Lowa State Univ. Press, Amer, Lowa U.S.A.

Tisdale, S. L., W. L. Nelson and I. D. Beaton. (1985). Soil fertility and fertilizers. 4th Ed. Macmillan Publishing Company, A division of Macmillan, Inc., New York, 754 pp.

Vessey, J. K. (2003): Plant growth promoting rhizobactria as biofertilizers. Plant and soil. 255:517-586. 
Hammad, S. A. et al.

Wahdan, M.E.M.(2004): Effect of using biofertilizers in minimizing the mineral fertilizers and improving sandy soil properties. Msc.Ain Shams.Univ.

Wang, K. R, Liu X. Zhou, W. J, Xie; X.L, Buresh, R. J. (2004): Effect of nutrient Recycling on soil fertility and sustainable Rice production. Journal of Agro Environment Science, 23, 1041-1045. (in Chinese).

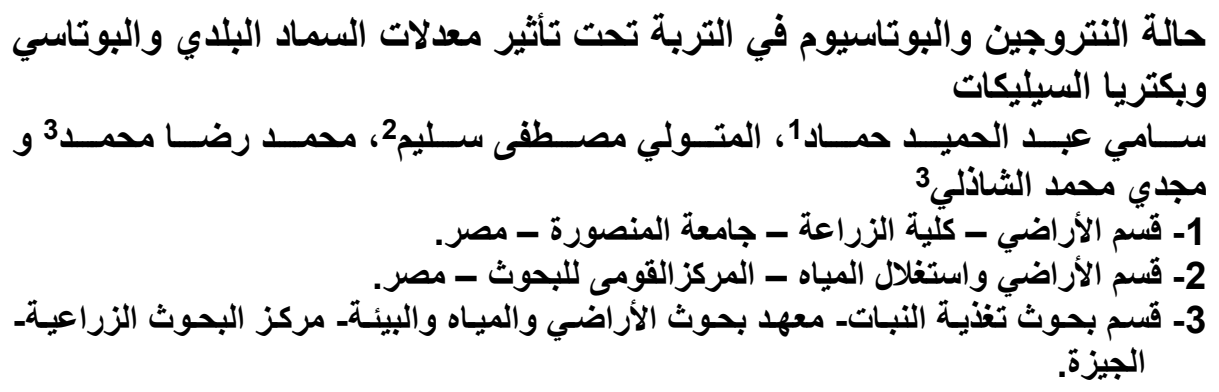

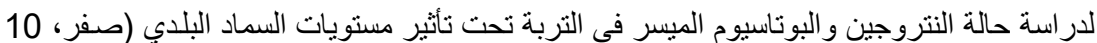

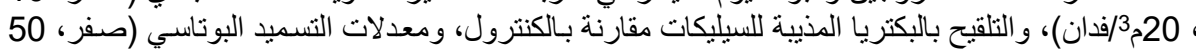

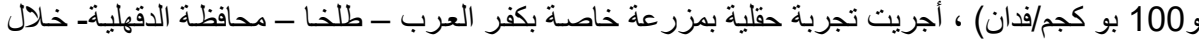

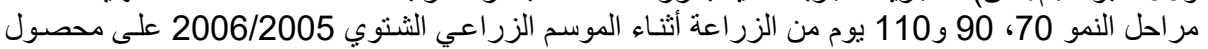
البطاطس صنف أسبونتا، ويمكن تلخيص أهم النتائج كالآتي:

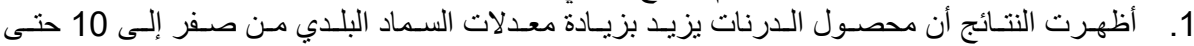

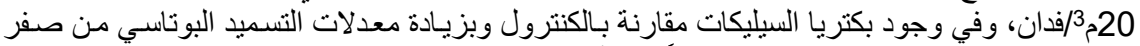

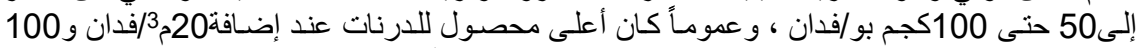

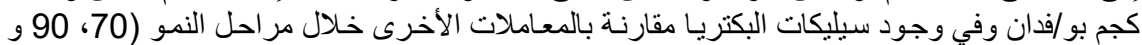
110

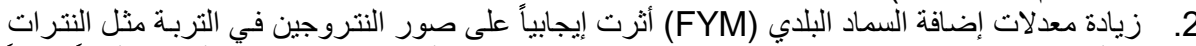

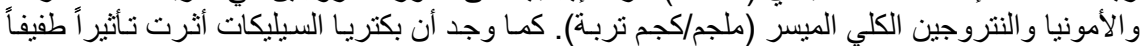

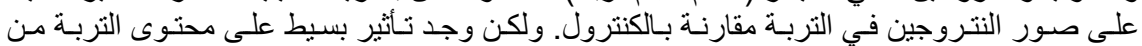

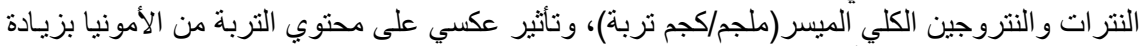

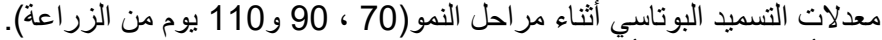

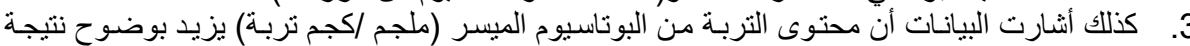

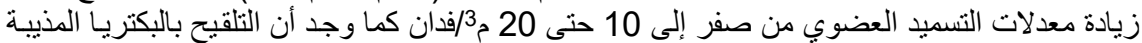

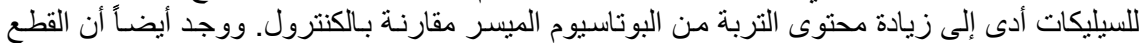

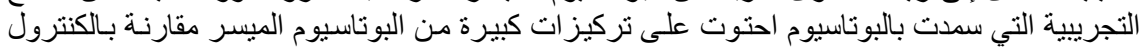

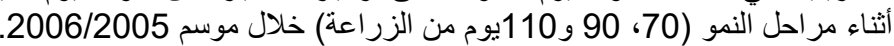

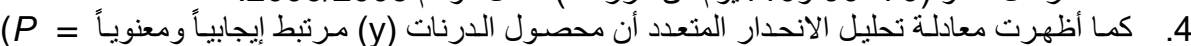

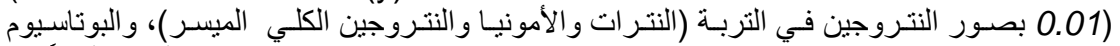

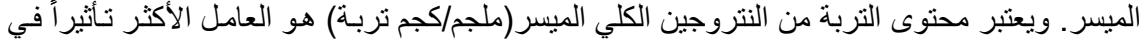

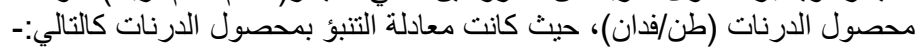

Tuber yield $\left(\right.$ ton fed ${ }^{-1}$ ) $=3.73+0.131$ soil-NO- $_{3}-0.165$ soil- $\mathrm{NH}^{+} 4+0.284$ soil-

TAN + 0.641 available soil-K. 